\title{
Konflikt polityczny i natura ludzka: Machiavellego rozważania nad starożytną Republiką Rzymską i nowożytną Florencją oraz ich wpływ na współczesną świadomość demokratyczną
}

\author{
Mario Marino (Nietzsche-Kolleg, Weimar)
}

\begin{abstract}
Może dziwić i wręcz budzić zażenowanie rekomendacja dzieła Machiavellego jako modelu demokratycznego myślenia i praktyki naszych czasów. Celem niniejszych rozważań jest pokazanie, jak koncepcja Machiavellego dotycząca antropologicznych fundamentów systemów politycznych, z jednej strony, oraz jego idea konieczności podejmowania działań $\mathrm{w}$ obrębie systemów politycznych na rzecz politycznej odpowiedzialności, godności, wolności i dobrobytu, z drugiej, mogą być inspirujące dla współczesnej debaty filozoficznej i refleksji politycznej. Rozważania składają się z trzech części: pierwsza podejmuje pewne mity narosłe wokół postaci Machiavellego; druga objaśnia jego antropologiczną teorię konfliktu politycznego. Celem trzeciej, końcowej części będzie wydobycie filozoficznego i politycznego potencjału myśli Machiavellego, a jednocześnie - wskazanie jej ograniczeń i momentów kontrowersyjnych.
\end{abstract}

\footnotetext{
* Chciałbym wyrazić swoją wdzięczność Uniwersytetowi im. Adama Mickiewicza w Poznaniu za zaproszenie mnie do prowadzenia cyklu wykładów o Machiavellim w Polsce oraz prof. Ewie Nowak i jej zespołowi za zachęcenie mnie do opublikowania niniejszej pracy. Stanowi ona pierwszą jeszcze niekompletną i prowizoryczną próbę aktualizacji odczytania Machiavellego z punktu widzenia współczesnej antropologii filozoficznej.
} 


\section{Myśliciel wielce kontrowersyjny w aureoli mitów}

Od samego początku nazwisko Machiavellego wywoływało i do dziś wywołuje

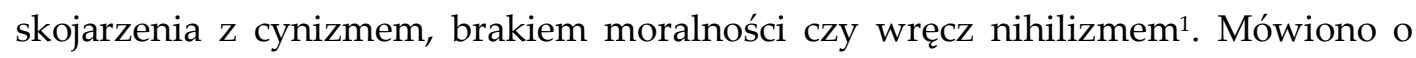
nim, że jest doradcą despotów, teoretykiem „racji stanu”; zwolennicy reformacji na równi z katolikami potępili go jako niszczyciela religijnych fundamentów ich społeczności. Polskie słowo makiaweliczny, lub jego włoski odpowiednik machiavelico, oznacza machinacje, hipokryzję, brak skrupułów. A jeśli ktoś zapyta: kim jest autor włoskiego powiedzenia: il fine giustifica $i$ mezzi? - większość ludzi natychmiast wskazałaby Machiavellego ${ }^{2}$. Poniżej pokazuję, że nie tylko nie jest autorem tego zdania, ale co więcej, nigdy nie myślał w ten sposób, ponieważ jego podejście do polityki nie było ideologiczne, a jego głównym zamiarem było wyjaśnienie logiki władzy politycznej oraz konieczności działania.

Niektórzy przedstawiciele oświecenia, republikanizmu i włoskiego Risorgimento (dziewiętnastowieczny włoski ruch patriotyczny) odwrócili tę „złą sławę" w "dobrą", gloryfikując Machiavellego jako pioniera nowoczesnego republikanizmu, ojca narodu i zakamuflowanego denuncjatora tyrańskich intryg i okrucieństw. Dopełniając wyidealizowany obraz Machiavellego, utożsamiali go z jeszcze inną fraza, tym razem taka, której rzeczywiście był autorem, a która pojawia się $\mathrm{w}$ jednym $\mathrm{z}$ jego ostatnich prywatnych listów adresowanych do Vettori'ego florenckiego przyjaciela i zarazem pierwszego czytelnika rękopisu Księcia: amo la patria mia più dell'anima3. Taka deklaracja uczuć patriotycznych, która jako żywo przypomina kontrowersyjne republikańskie hasło rodem ze Stanów Zjednoczonych, używane również przez nazistów w Buchenwaldzie: right or wrong, my country! brzmi jednoznacznie. Niemniej jednak to, co tymi słowy wyraża Machiavelli, bynajmniej nie miało źródła w jego sposobie myślenia, lecz było zwyczajowym

\footnotetext{
1 Przegląd recepcji Machiavellego w kulturze europejskiej znajdziemy w pracy G. Procacci'ego Machiavelli nella cultura europea dell'età moderna, Roma 1995. Jeśli chodzi o życiorys Machiavellego, to przede wszystkim odsyłam do M. Viroli'ego Il sorriso di Niccolò. Storia di Machiavelli, Roma 1998 (dostępne również w przekł. ang. i nm.). Wcześniejsze, najpełniejsze biografie Machiavellego napisane zostały przez P. Villari'ego, Niccolo Machiavelli e i suoi tempi, Milano 1912-1914, O. Tommasiniego La vita e gli scritti di Niccolo Machiavelli nella loro relazione col machiavelismo, Torino-Roma 1883-1911, a zwłaszcza spisana w drugiej połowie dwudziestego stulecia przez R. Ridolfiego Vita di Niccolo Machiavelli, Roma 1954, dostępna również w jęz. ang.

${ }^{2}$ Angielski przekład aforyzmu: the end justifies the means. W języku polskim funkcjonuje określenie: „cel uświęca środki”, co nie jest ścisłym tłumaczeniem oryginału: „cel usprawiedliwia środki” [przyp. tłum.].

${ }^{3}$ Machiavelli do Vettori'ego, 16 kwietnia 1525 w: N. Machiavelli, The Chief Works and Others, tłum. A. Gilbert, Durham - London, 1989, vol. II, 1010. W przekładzie Gilberta: I love my country more than my own soul (przekład zmodyfikowany).
} 
sloganem wypowiadanym przez krajan Machiavellego w XIV i XV wieku. Ponadto, mimo swych republikańskich inklinacji, Machiavelli jasno wyraził w Księciu tezę, że nie ma doskonałej, idealnej formy rządu: E molti si sono immaginati republiche e principati che non si sono mai visti né conosciuti in vero essere ${ }^{4}$.

Tych kilka spostrzeżeń powinno już wystarczyć jako demonstracja tezy, że każda epoka i każdy czytelnik dzieł Machiavellego wyrabia sobie na jego temat inne wyobrażenie. Każda jednak interpretacja zawiera informację, a każda informacja z osobna wymaga historycznej kontekstualizacji i krytycznego zbadania. Jest to szczególnie ważne w przypadku myśliciela, który odpowiada na fundamentalne historyczne, polityczne i filozoficzne pytania w tak fascynujący, bezkompromisowy i wpływowy sposób, jak czyni to Machiavelli. Dlatego też w mojej pracy sięgam do tekstów źródłowych, by wskazać ograniczenia tradycyjnych interpretacji, a także na aktualność Machiavellego teorii konfliktu, którą opierał na rozważeniu przyczyn wielkości republiki rzymskiej i upadku średniowiecznej i renesansowej Florencji. Zanim przejdę do analizy tekstów Machiavellego chciałbym przede wszystkim pozbawić czytelnika skojarzeń pomiędzy Machiavellim a zasadą „cel uświęca środki", ponieważ jest to wciąż najbardziej rozprzestrzenione uprzedzenie wobec niego, a zarazem największa przeszkoda w poprawnej interpretacji i ponownym przyswojeniu jego myśli.

\section{O pochodzeniu makiawelicznego mitu: „cel uświęca środki”}

Jak już zostało powiedziane, Machiavelli nie jest autorem ani zdania, ani myśli, że „cel uświęca środki". Istnieje jednak pewien ustęp wzięty $\mathrm{z}$ jego komedii Mandragora, który uległ szybkiej instrumentalizacji w tym właśnie sensie i spowodował dyskredytację jego myśli jako niemoralnej: jest nim rada udzielona Donnie Lukrecji przez brata klasztornego Tymoteusza, mówiąca, że el fine si ha a riguardare in tutte le cose (akt 3, scena 11) ${ }^{5}$. Fabuła sztuki jest dobrze znana ${ }^{6}$, poddajmy zatem bliższej analizie jej tekst, z ową radą na czele.

\footnotetext{
${ }^{4}$ N. Machiavelli, Ksią̇̇e, tłum. W. Rzymowski. Unia Wydawnicza Verum, Warszawa 2005, 92: „wielu bowiem pisarzy wymyśliło sobie rzeczpospolite i monarchie, które w rzeczywistości ani widziane były, ani znane".

${ }^{5} \mathrm{~W}$ zmodyfikowanym przekładzie Gilberta mamy: the end must be considered in everything. Polski przekład Boyègo znacząco odbiega od oryginału: "cel uświęca środki”. Chcąc oddać sens zmodyfikowanej wersji tłumaczenia Gilberta, którą posłużył się autor, tłumaczę: „należy zawsze mieć na uwadze cel" [przyp. tłum.].

${ }^{6}$ We Florencji początków XVI w. młody mężczyzna o imieniu Kallimach zakochuje się bez pamięci w żonie Messera Nicii, olśniewającej i pobożnej damie o imieniu Lukrecja. Pragnie, by stała się jego za wszelką cenę, ale nie wiedząc, w jaki sposób zabrać się do dzieła, korzysta z rady chytrego Liguria,
} 
Pierwszą uwaga jaką należy poczynić jest to, że nie mamy w tym wypadku do czynienia z traktatem teoretycznym, ale z komedia, co oznacza, że znaczenie słów i fraz zależy przede wszystkim od sytuacji dramatycznej oraz od osób występujących w dramacie. Następnie, zauważyć należy, że z czysto teoretycznego punktu widzenia fraza wypowiadana przez Tymoteusza w sztuce oraz ta, którą się zwykło przypisywać Machiavellemu, nie są identyczne.

Zacznijmy od sytuacji dramatycznej: Tymoteusz musi przekonać Lukrecję, że plan Liguria nie jest sprzeczny z moralnością i religią. Aby to uczynić, odwołuje się do wszelkich możliwych argumentów ${ }^{7}$. Oto one: 1) rozróżnienie na prawo ogólne i sytuację wyjątkową; 2) zniekształcający wpływ strachu na postrzeganie rzeczywistości 3) prymat pewnego dobra nad niepewnym złem; 4) skupianie się na celu raczej niźli na środkach; 5) małżeńska powinność uszczęśliwienia własnego męża; 6) kobieca powinność „przysparzania duszyczek Stwórcy Niebieskiemu”; 7) rozróżnienie pomiędzy grzechami powszednimi i ciężkimi; 8) pouczenia Biblii. Z tej perspektywy staje się jasne, że argument o prymacie celu nad środkami jest jedynie częścią strategii perswazyjnej, jest tylko jednym pośród wielu innych, i nic nie wskazuje w tekście na to, że jest to argument najważniejszy.

Przyjrzyjmy się teraz budowaniu postaci dramatu i zastanówmy, czy można utożsamić Machiavellego z bratem Tymoteuszem? Od samego początku postać Tymoteusza kreślona jest negatywnie: po raz pierwszy jego imię wspomniane jest w szóstej scenie aktu drugiego, kiedy Kallimach ujawnia Messerowi Nicii plan mający na celu uczynienie Donny Lukrecji brzemienną. Przekonanie jego cnotliwej żony do tak haniebnego, skandalicznego i kryminalnego aktu wydaje się niegodziwemu Messerowi Nicii nie lada zadaniem, dlatego autor planu, Ligurio, sugeruje, by

znajomego Nicii. Ligurio uknuwa misterny plan oparty na znajomości najbardziej intymnego problemu ich małżeństwa: tak się składa, że Messer Nicia jest bardzo rozczarowany brakiem potomstwa, o co obwinia żonę i domniemaną bezpłodność. Plan zakłada, że Kallimach wda się w rolę lekarza medycyny i zaproponuje Nicii niezawodna, lecz ryzykowną terapię wyleczenia bezpłodności Lukrecji. Lukrecja ma spożyć napój z mandragory, który czyni kobietę płodną, ale jednocześnie mężczyzna, który ją zapłodni umrze w przeciągu ośmiu dni w wyniku działania trucizny. Nicia nie chce umierać, ale chcąc mieć syna, zgadza się na pomysł Liguria, by wykorzystać do tego celu żebraka, bezdomnego, lub jakiegoś obcego podróżnika, który zapłodni Lukrecję i umrze zamiast Nicii. Nicia nie podejrzewa, że za przebraniem ubogiego podróżnego kryć się będzie Kallimach, dzięki czemu jego nocne miłowanie się z Donną Lukrecją przebiegnie bez zakłóceń.

7 Zob. N. Machiavelli, Mandragola, tłum. E. Boyè. Wydawnictwa Artystyczne i Filmowe, Warszawa 1986, akt 3, scena 9. 
skorzystać z pomocy spowiednika Donny Lukrecji, brata Tymoteusza, o którym wieść niesie, że jest zepsutym i podstępnym mnichem ${ }^{8}$.

Następujące później sceny potwierdzają ten negatywny obraz. W swym pierwszym monologu Tymoteusz objawia się jako chciwy i pozbawiony skrupułów oportunista. Nie przejmuje się udziałem w oszustwie, skoro ma dzięki temu odnieść korzyść majątkową: dla pieniędzy nadużyje swojego autorytetu, by nakłonić Donnę Lukrecję do niemoralnego czynu' ${ }^{9}$ Już kiedy po raz pierwszy pojawia się na scenie (scena 3, akt 3), daje faktyczny dowód swojej podstępnej natury. Jego spotkanie i dialog z parafianką przy wyjściu z kościoła jest autentycznym popisem dwuznaczności. Pozornie dialog nawiązuje do zwyczajowych praktyk kościelnych (jak np. msza za dusze zmarłych bliskich, uczestnictwo w spowiedzi) i lęków związanych z praktyką wiary katolickiej (lęk o dusze niewierzących). Jednak owa nabożnica wciąż napomyka o swych pragnieniach seksualnych, czego zakonnik bynajmniej nie potępia, a wręcz zdaje się je pochwalać. Również sławna scena pomiędzy Tymoteuszem, Lukrecją i jej matką Sostratą dobitnie pokazuje, że Tymoteusz sprzeniewierza się swemu powołaniu księdza, dokonując perwersyjnej interpretacji Biblii i teologii katolickiej dla korzyści majątkowej. Przykładowo, to, do czego stara się nakłonić Lukrecję, definuje jako grzech powszedni, nawet jeśli w wyniku działania trującej mikstury ktoś poniesie śmierć, z czego - co istotne Lukrecja i jej mąż zdają sobie sprawę ${ }^{10}$. Kolejnym zabiegiem retorycznym ojca Tymoteusza jest pouczenie Lukrecji zaczerpnięte z pierwszej księgi Biblii o córkach Lota spółkujących z własnym ojcem w przeświadczeniu, że są ostatnimi pozostałymi

\footnotetext{
${ }^{8}$ Mandragora, akt 2, scena 6: (Kallimach) Chi disporra el confessoro, tu? [Ligurio:] Io, e danari, la cattività nostra, loro. Por. Mandragola: „A co nakłoni spowiednika? [Ligurio:] Ja, pieniądze, podłość nasza i wasza" [przekł. zmodyfikowany - uwaga tłum.].

${ }_{9}^{9}$ Mandragora, akt 3, scena 9: Io ci sono giuntato; nondimeno, questo giunto è con mio utile. Messer Nicia e Callimaco sono rocchi, e da ciascuno, per diversi rispetti, sono per trarre assai; la cosa conviene stia secreta, perché l'importa cosi a loro, a dirla, come a me. Sia come si voglia, io non me ne pento (...). Madonna Lucrezia è savia e buona: ma io la giugnerò in sulla bontà. (N. Machiavelli, Mandragola, 151: „Nie ulega wątpliwości, że chcieli mnie na hak przywieść, ale sądzę, że przy tym ogniu i ja będę sobie mógł pieczeń upiec. Messer Nicia i Kallimach to bogacze i od każdego z nich można będzie wiele pieniążków wyciągnać. Sprawa musi pozostać w tajemnicy. Na sekrecie zależy równie im, jak i mnie. A zresztą niech będzie jak chce! Też się mam o co martwić ?! [...] Madonna Lukrecja jest mądra, cnotliwa i dobra. Może jednak właśnie z powodu zbytniej dobroci, weźmie się na lep.").

${ }^{10}$ Akt 3, scena 11: Io vi giuro, madonna, per questo petto sacrato, che tanta coscienza vi è ottemperare in questo caso al marito vostro, quanto vi é mangiare carne el mercodedí, che è un peccato che se ne va con l'acqua benedetta. (Mandragola, 161-162: „Przysięgam wam, madonno, na tę pierś poświęcana, że grzech to niewielki, całkiem tak, jakbyście w piątek zjedli kawałek mięsa. Jak wiecie parę kropel święconej wody, wystarcza w tym wypadku, aby otrzymać rozgrzeszenie.")
} 
przy życiu kobietami na świecie ${ }^{11}$. Popełniają więc akt kazirodztwa, by zapewnić przetrwanie ludzkości. Dla każdego oczywista jest różnica pomiędzy sytuacją wyjątkową spowodowaną koniecznością ratowania ludzkości przed wyginięciem, a egoistyczną pobudką posiadania potomka. Należy teraz zapytać: czy to możliwe, by Machiavelli powierzył esencję swej własnej myśli postaci ojca Tymoteusza, który z całą pewnością przedstawiony jest jako paradygmatyczny model zepsucia i podwójnej moralności Kościoła Katolickiego jego czasów? Czyż taki zabieg nie byłby zbyt makiaweliczny nawet dla samego Machiavellego?

Nawet gdybyśmy wyjęli z kontekstu zdanie Tymoteusza „należy zawsze mieć na uwadze cel" (zob. przyp. 5) i przeanalizowali je z zupełnie abstrakcyjnego punktu widzenia, to również $\mathrm{w}$ tym wypadku znaczenie tego zdania nie zgadzałoby się ze znaczeniem maksymy: "cel uświęca środki”. Właściwy teoretyczny sens wypowiedzianej przez Tymoteusza frazy jest taki, że jeśli ktoś podejmuje się jakiegoś działania, to musi mieć na uwadze jego cel oraz musi znaleźć najbardziej efektywne połączenie między nim a środkami: bez tej relacji nie można liczyć na skuteczne działanie, ani w ogóle mówić o działaniu we właściwym sensie tego słowa. Strukturę działania tworzą z jednej strony cele, a z drugiej, odpowiednie środki potrzebne do ich realizacji. Sformułowanie „cel uświęca środki” nie jest natomiast opisem takiej struktury, nie wskazuje warunków działania, mówi jedynie o tym, kiedy działanie, niezależnie od tego, jakim ono jest, można uważać za moralnie usprawiedliwione: pierwsze zdanie określa pewne ogólne i, można by powiedzieć, formalne warunki działania, podczas gdy drugie dotyczy moralnej legitymizacji działania. Można zatem podsumować, że ani z filozoficznego, ani z teoretycznego punktu widzenia podejścia i myśli Machiavellego nie można streścić w sławnej maksymie „cel uświęca środki”.

\section{Konflikt polityczny i natura ludzka. \\ Corpus politicum i konflikt polityczny w Księciu (rozdział IX)}

Po raz pierwszy Machiavelli porusza problem konfliktu politycznego w dziewiątym rozdziale Księcia: In ogni città si truovano questi dua umorsi; e nasce da questo, che il populo desidera non essere comandato né oppresso da' grandi, e li grandi desiderano comandare et opprimere el populo: e da questi dua appetiti diversi nasce nelle città uno de' tre

\footnotetext{
11 Tamże, 161: „Biblia mówi, że córeczki Lota, sądząc, że same jedne na świecie pozostały, ojcu się oddawały, ponieważ jednak intencje ich były dobre - więc nie grzeszyły!"
} 
effetti, o principato o libertà o licenzia (IX, 2) ${ }^{12}$. Tłumaczenie Gilberta terminu umori przez "partie" lub „frakcje” (Gilbert, I, 39: two opposing parties) ${ }^{13}$ jest mylące, ale można się nim posłużyć jako punktem wyjścia dla poprawnej interpretacji sensu myśli Machiavellego. Machiavelli nie chce tutaj bowiem powiedzieć, że lud i możni są u zarania dwiema "partiami” tj. dwoma politycznymi ugrupowaniami, dwiema postaciami samoorganizacji reprezentującymi swoje interesy. Są przede wszystkim dwiema podstawowymi, przeciwstawnymi tendencjami, dwiema kontrastującymi ze sobą siłami organizmu politycznego. Machiavelli świadomie posługuje się terminami medycznymi, umori (temperamenty) i appetiti (apetyty), ustanawiając w ten sposób analogię pomiędzy organizmem politycznym i biologicznym: życie obu ciał uzależnione jest od właściwych im kontrastujących temperamentów; życie jest walką o autonomię, a walka ta z konieczności toczy się pomiędzy dwiema opozycyjnymi siłami ${ }^{14}$.

Przytoczony wyżej cytat zawiera już w sobie zarys Machiavellego ujęcia konfliktu społecznego, ale nie daje się go jeszcze zastosować do porównawczej

${ }^{12}$ Machiavelli, Książe, 71: „W każdym bowiem mieście istnieją dwa różne temperamenty [tj. ludu i wielkich] pochodzące stąd, iż lud nie chce znosić panowania i ucisku wielkich, wielcy zaś dążą do opanowania i uciskania ludu. Ze starcia tych dwu apetytów przeciwnych powstaje w skutku jeden $\mathrm{z}$ trzech następujących wyników: albo monarchia, albo wolność, albo bezrząd" [przekł. zmodyfikowany].

${ }^{13}$ To samo w staroangielskim przekładzie Księcia W.K. Marriotta dostępnym w internecie dla szerszej międzynarodowej publiczności: two distinct parties (http://ebooks.adelaide.edu.au./m/machiavelli/niccolo/m149p/chapter9.html) (przyp. tłum.).

${ }^{14}$ Wielu komentatorów słusznie podkreślało znaczenie tradycji medycyny starożytnej mającej korzenie w Grecji, rozwijanej przez naukę arabską średniowiecza aż do renesansu dla głębszego zrozumienia myśli Machiavellego. Tommasini powiązał bezpośrednio idee Machiavellego, virtù i fortuna z tradycją galeńską (O. Tommasini, La vita e gli scritti di Niccolò Machiavelli, Torino 1911, t. 2, 39, przypis 2: Galen's Tyche is Machiavelli's occasion, the word virtù indicate in the Florentine politician [i.e. Machiavelli] nothing but what Galen and physicians were used to designate with the name of virtus). Badaloni z kolei szczególnie podkreślał znaczenie, jakie odgrywała tradycja arystotelesowska, zmodyfikowana przez Awicennę i pośrednio inspirująca Machiavellego, przez współczesne mu prace humanistyczne, w zdefiniowaniu kontekstu myśli Machiavellego (N. Badaloni, Natura e società in Machiavelli. Studi Storici, X, 4, Październik-Grudzień 1969, 675-708, w: N. Badaloni, Inquietudini e fermenti di libertà, Pisa 2005, 1-27, tutaj 18-19). Można zacytować kilka ustępów, w których Machiavelli posługuje się wyrażeniami medycznymi m.in. Discorsi, III, 1, 9: e perché nel processo del tempo quella bontà si corrompe, se non interviene cosa che la riduca al. segno, ammazza di necessità quel corpo. E questi dottori di medicina dicono, parlando de corpi degli uomini, quotidie aggregatur aliquid, quod quandoque indiget curatione (N. Machiavelli, Rozważania nad pierwszym dziesięcioksięgiem historii Rzymu Liwiusza. Unia Wydawnicza Verum, Warszawa 2005, 301: “Ponieważ zaś dobro to z biegiem czasu niszczeje, należy je w jakiś sposób ratować, bo w przeciwnym wypadku organizm musi umrzeć. Dlatego lekarze mawiają o organizmie ludzkim [że co dzień wchłania w siebie coś, co w swoim czasie wymagać będzie leczenia" - tłum. Grzybowskiego). 
analizy losów starożytnej Republiki Rzymu i nowożytnej Republiki Florencji. We wspomnianym dziewiątym rozdziale Księcia Machiavelli skupia się wyłącznie na pytaniu o to, w jaki sposób polityczny organizm republiki może zamienić się w księstwo. Powodem tego jest dynamika konfliktu społecznego: jedna ze stron (lud albo możni) może zdecydować się nobilitować pewną jednostkę po to, by zyskać jej protekcję przed zakusami drugiej strony: Vedendo e' grandi non potere resistere al. populo, cominciano a voltare la reputazione a uno di loro e fannolo principe per potere sotto la sua ombra sfogare il loro appetito; il populo ancora, vedendo non poter resistere a' grandi, volta la reputazione a uno e lo fa principe per essere con la sua autorità difeso (Il Principe, IX, 3) ${ }^{15}$.

Ktoś mógłby ulec pokusie cynicznego, utylitarystycznego komentarza, że "gdzie dwóch się bije, tam trzeci korzysta". Machiavelli nie zgodziłby się jednak z takim uproszczeniem własnej myśli: jego zdaniem rola księcia pociąga za sobą największą odpowiedzialność. Rządzenie wspólnotą polityczną jest prawdopodobnie najbardziej ekscytującym, ale zdecydowanie najtrudniejszym i najniebezpieczniejszym zadaniem, jakiego może podjąć się człowiek, dlatego też książę nie może spocząć na laurach: nigdy nie powinien tracić czujności.

Wydaje się, że opis konfliktu społecznego, który daje Machiavelli, czyni go większym zwolennikiem żądań ludu: mówi nam, że ludzie czują się ciemiężeni i chcą jedynie protekcji, podczas gdy możni snują intrygi, by osiągnąć bezwarunkowe zaspokojenie swoich ambicji [z krzywdą dla ludu - uzup. tłum.]. Niemniej jednak Machiavelli nie dokonuje moralnego potępienia możnych, ich obłudy czy ambicji: wytyczanie i realizowanie celów zgodnie z własną ambicją jest nieodzownym elementem życia politycznego, a sama obłuda może być bronią polityczną. Prawdą jednak jest to, że Machiavelli sympatyzuje w większym stopniu z ludem niż z możnowładztwem, gdyż: quello del populo è più onesto fine che quello de' grandi, volendo questi opprimere e quello non essere eppresso (Il Principe, IX, 6) ${ }^{16}$. Obrona własnej wolności jest pierwszym warunkiem zapewnienia godności i bezpieczeństwa.

\footnotetext{
${ }^{15}$ Książę, 71: „Jeśli bowiem wielcy widzą, że naporowi ludu nie będą mogli sprostać, wówczas starają się jednemu spośród siebie stworzyć wielkie imię i czynią go księciem, ażeby pod cieniem jego tronu zadowolić swe apetyty. Podobnież czyni lud, skoro widzi, że panom nie podoła, otacza chwałą jakiegoś jednego męża i robi go księciem, aby mieć w nim tarczę swej obrony" [tłum. zmodyfikowane]. ${ }^{16}$ „Gdyż te ostatnie są o wiele [szlachetniejsze] niźli żądania magnatów. Magnaci chcą uciskać lud, lud chce tylko tego, by nie być uciskanym" [tłum. Grzybowskiego].
} 


\section{Konflikt polityczny w Republice Rzymskiej (Rozważania, część I, rozdział 4)}

Kilka lat później Machiavelli wyraźnie stwierdza, że podana w rozdziale dziewiątym Księcia ogólna definicja konfliktu społecznego stanowi klucz do właściwego wyjaśnienia poszczególnych przypadków historycznych. Mamy tego przykład w księdze pierwszej, rozdziale czwartym Rozważań, gdzie Machiavelli stawia tezę, że „waśnie między szlachtą a ludem” sprawiły, iż Republika Rzymska stała się „wolna i potężna"17. Stanowczo odrzucając wyidealizowany obraz pacyfistycznych wspólnot politycznych, Machiavelli utrzymuje że coloro che dannono i tumulti intra $i$ nobili e la plebe, mi pare che biasimino quelle cose che furono prima causa del tenere libera Roma (...) e (...) non considerino come $e^{\prime}$ sono in ogni republica due umori diversi, quello del popolo, e quello de' grandi; e come tutte le leggi che si fanno in favore della libertà, nascano dalla disunione loro (Discorsi, I, 4, 1), to znaczy ze sporu pomiędzy ludem a możnymi.

Nie tylko Machiavelli powtarza sformułowanie z Księcia („dwa różne temperamenty, ludu i wielkich"), ale jednocześnie opowiada się po stronie temperamentu ludu, podkreślając, że $i$ desiderii dei popoli liberi rade volte sono perniziosi alla libertà, perche e' nascono o da essere oppressi, o da suspizione di avere ad essere oppressi $(\mathrm{I}, 4,1)^{18}$. Innymi słowy, walka ludu przeciw opresji jest gwarantem większej wolności, ponieważ zmierza do zaspokojenia większości bez wyrządzenia krzywdy mniejszości. Z perspektywy Machiavellego taki był zawsze rezultat walk politycznych w antycznej Republice Rzymskiej, czego bynajmniej nie można powiedzieć o nowożytnej Florencji. Machiavelli nie wspomina jednak wprost o Florencji w pierwszej części czwartego rozdziału Rozważań, czyni jedynie aluzję do tej rozbieżności przez wyróżnienie Rzymu na tle pewnych miast, których rządzący przywykli do fizycznej eliminacji wrogów, albo przez ich zabijanie, albo skazywanie na banicję. Bezpośrednio porównuje Machiavelli Rzym i Florencję dopiero pod koniec życia w Istorie Fiorentine.

\section{Historie florenckie i punkt kulminacyjny rozważań Machiavellego nad konfliktem politycznym}

Ujęcie konfliktu politycznego, jakie zamieszcza Machiavelli w swoim ostatnim głównym dziele, a dokładniej mówiąc w pierwszym rozdziale księgi trzeciej stanowi, moim zdaniem, punkt kulminacyjny w jego refleksji na ten temat, zarówno z teoretycznego jak i literackiego punktu widzenia. Po pierwsze, stylistycznie i

\footnotetext{
${ }_{17}$ N. Machiavelli, Rozważania nad pierwszym dziesięcioksięgiem historii Rzymu Liwiusza, 148.

${ }^{18}$ Tamże, 149: „Żądania ludu wolnego rzadko kiedy okazują się szkodliwe dla jego wolności, gdyż przyczyną ich jest zwykle albo wywierany ucisk, albo obawa, że ucisk taki wkrótce spadnie".
} 
logicznie jest ono najbardziej radykalne, z tego względu, że owo porównanie [Rzymu i Florencji - uzup. tłum.] przechodzi w serię dramatycznych i nieprzezwyciężalnych opozycji, które są konsekwentnie wyprowadzane z opracowania tylko jednego pojęcia. Po drugie, jest ono jednocześnie najbardziej ogólne i analityczne, a więc jest najbardziej kompletnym i rozstrzygającym przedmiotem dyskusji, dlatego że Machiavelli ustanawia $\mathrm{w}$ nim pierwszą uniwersalną zasadę wyjaśniania równoznaczną $\mathrm{z}$ kryterium interpretacyjnym przypadków historycznych, których tutaj wymienia więcej niż jeden.

Machiavelli rozpoczyna rozdział od podjęcia argumentu o różnych temperamentach, by zdefiniować ogólny powód konfliktów społecznych, oraz by wyjaśnić politowania godną [polityczną - uzup. tł.] sytuację średniowiecznej i renesansowej Florencji: Le gravi e naturali inimicize, che sono intra gli uomini popolari e $i$ nobili, causate da il volere questi comandare e quegli non ubbidire, sono cagione di tutti $i$ mali che nascano neile città; perché da questa diversita di umori tutte l'altre cose che perturbano le repubbliche prendono il nutrimento loro. Questo tenne disunia Roma, questo (...) ha tenuto diviso Firenze (Istorie Fiorentine, III, 1) ${ }^{19}$. Machiavelli jest świadomy faktu, że Rzym cieszył się przez szereg stuleci nienaruszalną wolnością, podczas gdy Florencja swoją kruchą niezależność bardzo szybko utraciła, oraz tego, że Rzym był w stanie zdominować świat, podczas gdy Florencja pozostała małym państwemmiastem pośród innych, sobie podobnych włoskich państw-miast. Teoria konfliktu politycznego będzie spójna wtedy i tylko wtedy, gdy znajdziemy przekonującą odpowiedź na pytanie, dlaczego jeden i ten sam czynnik wywołuje tak różne rezultaty. Odpowiedź, jakiej udziela Machiavelli jest dla mnie zupełnie genialnym i zaskakującym, nowoczesnym zastosowaniem jego teorii: powiada on, że organizm polityczny rośnie $\mathrm{w}$ siłę, gdy celem gry politycznej nie jest wyłączenie z władzy politycznej, lecz przeciwnie, jej postępujący podział, lub, jak powiedzielibyśmy dzisiaj, powiększenie i konsolidacja demokracji. La quale diversità di effetti conviene che sia dai diversi fini che hanno avuto questi duoi popoli causata; perché il popolo di Roma godere i supremi onori insieme con i nobili desiderava, quello di Firenze per essere solo nel

\footnotetext{
${ }^{19}$ N. Machiavelli, Historie florenckie. PWN, Warszawa-Kraków 1990, 135: „Wielkie nieprzyjaźnie, jakie z natury swej powstają między szlachtą a ludem są tym spowodowane, że pierwsi chcą rozkazywać, a drudzy nie chcą słuchać. Tu znajduje się przyczyna wszelkiego zła w miastach. Z takiej różnicy poglądów rodzą się bowiem wszystkie inne kłopoty, jakie nękają republiki. To sprawiło, że Rzym był wewnętrznie podzielony $i$ to [...] sprawiło, że Florencja pozostawała rozdarta..." (tłum. zmodyfikowane).
} 
governo sanza che $i$ nobili ne partecipassero, combatteva (III, 1) ${ }^{20}$. Mówiąc wprost: lud starożytnej republiki rzymskiej nie zaprzeczał wartości i roli pełnionej przez możnowładztwo, ale starał się mieć jak największy wpływ na swój własny los. Znajdowanie kompromisu z ludem nie oznaczało zatem dla możnych utraty czy osłabienia ich statusu, lecz prawne zabezpieczenie przywilejów własnych oraz ludu. E perché il desiderio del popolo romano era più ragionevole, venivono ad essere le offese ai nobili più sopportabili; tale che quella nobilità facilmente e sanza venire alle armi cedeva; $d i$ mono che, dopo alcuni dispareri, a creare una legge dove si sodisfacesse al. popolo, e i nobili nelle loro dognità rimanessero, convenivano (Istorie Fiorentine, III, 1) ${ }^{21}$.

Nazywając „uczciwym” żądanie ludu, miał Machiavelli w Księciu na myśli żądanie reprezentowane przez lud Republiki Rzymskiej - a nie lud Florencji. Ten ostatni bowiem, dążąc do wykluczenia możnych z organizmu politycznego, zmusił ich tym samym do walki o przetrwanie, która w konsekwencji osłabiła ten organizm (skoro, jak pamiętamy, jest on współtworzony przez oba te usposobienia). Il desiderio del popolo fiorentino era ingiurioso e ingiusto, tale che le nobiltà con maggiori forze alle sue difese si preparava, e perciò al. sangue e all'esilio si veniva de' cittadini; e quelle leggi che di poi si creavano, non a comune utilità, ma tutte in favore del vincitore si ordinavano. To samo nastąpiło w przypadku porażki możnych. Zaadaptowanie się możnych do nowego porządku oznaczało ich autodegradację, a więc zepsucie istotnej części ciała politycznego. Ma in Firenze, vincendo il popolo, i nobili privi de' magistrati rimanevano; $e$ volendo racquistargli era loro necessario con i governi, con lo animo e con il modo del vivere, simili ai popolani non solamente essere ma parere (...); tale che Firenze sempre più umile e più abbietto divenne (tamże, III, 1) 22. To oznacza również, że treścią teorii konfliktu politycznego Machiavellego są nie tylko zmiany w porządkach konstytucyjnym i prawnym (lub, bardziej ogólnie, instytucyjne mechanizmy władzy), ale również

\footnotetext{
${ }^{20}$ Tamże, 136: „Skutki tak różne powstały z odmiennych celów, jakie przed sobą widziały oba narody. Lud bowiem Rzymu pragnął korzystać z najwyższych zaszczytów razem ze swymi patrycjuszami, lud florencki zaś walczył o wyłączność w rządzie, bez udziału możnowładczych rodów."

${ }^{21}$ Tamże, 136: „Ponieważ żądania ludu rzymskiego były bardziej rozsądne [...] toteż ci ostatni bez walki ustępowali ludowi, po paru sprzeczkach tworząc prawa zadość czyniące żądaniom ludu, a patrycjuszy pozostawiające przy ich godnościach."

${ }^{22}$ Tamże, 136-137: „Inaczej było we Florencji. Tu żądania ludu były krzywdzące i niesprawiedliwe. Dlatego też szlachta z całą swą siłą broniła się, i dlatego tyle krwi mieszkańców Florencji spłynęło, tylu obywateli poszło na wygnanie. Uchwalone potem prawa nie służyły wspólnym celom, lecz podporządkowane były zwycięzcom. [...] We Florencji natomiast, kiedy zwyciężył lud, wyższe stany wykluczono z rządu. Usunięci patrycjusze, jeżeli chcieli odzyskać udział w rządzie, musieli nie tylko zmienić swe poglądy i sposób rządzenia, ale i sposobem życia upodobnić się do ludu i takimi też okazać się na zewnątrz. [...] Toteż Florencja stawała się coraz bardziej upadła i uniżona."
} 
modyfikacje wartości, zwyczajów i kulturowych wzorów klas społecznych (tzn. ich ethosu i stylu życia) $)^{23}$.

Podsumowując konsekwencje obu historycznych wzorów konfliktu politycznego będących przedmiotem namysłu Machiavellego, można powiedzieć, że podczas gdy lud rzymski stał się bardziej cnotliwy i wielki przez naśladowanie możnych, florenckie możnowładztwo stało się bardziej plebejskie. Konflikt polityczny Republiki Rzymskiej spowodował awans społeczny klas niższych bez jednoczesnej degradacji klas wyższych, we Florencji natomiast spowodował obniżenie statusu drugich bez awansu pierwszych. Lud zyskał na większym udziale w procesie politycznym Republiki Rzymskiej, podczas gdy we Florencji tylko część społeczeństwa miała dostęp do władzy politycznej.

\section{Kilka uwag końcowych}

Zakończę moje rozważania trzema uwagami o aktualności Machiavellego w naszych czasach. Wydaje mi się, że jego teoria konfliktu politycznego mogłaby w kontekście współczesnej debaty politycznej dostarczyć filozoficznego wyjaśnienia klęski komunizmu. Ta sama teoria wydaje mi się znajdować bardzo szerokie zastosowanie w kontekście filozofii współczesnej jako dowód na potężny i nierozerwalny sojusz pomiędzy myślą antropologiczną i polityczną. Obie te perspektywy skłaniają do refleksji nad wciąż otwartymi problemami postkomunistycznych społeczeństw.

\section{O klęsce dwudziestowiecznego komunizmu}

$\mathrm{Na}$ pierwszy rzut oka istnieje zaskakująco wiele podobieństw pomiędzy Machiavellim a Marksem: obaj postrzegali życie każdego systemu politycznego jako walkę pomiędzy dwiema opozycyjnymi siłami. Niemniej jednak Marks uważał, że byłoby nie tylko możliwe, ale wręcz konieczne, by jedna klasa ostatecznie i definitywnie zatriumfowała i zastąpiła drugą. W przeciwieństwie do tego stanowiska, Machiavelli był $\mathrm{w}$ pełni przekonany, że obie te siły są niezbędne dla zdrowego funkcjonowania organizmów politycznych. W mojej opinii taka rozbieżność w pojęciu konfliktu i jego rezultatu u obu myślicieli zależy od podstawowej różnicy dotyczącej filozoficznego ujęcia tych sił. Marks interpretował owe siły jako byty ekonomiczne, rozumiane jako dwa skutki zdeterminowanej organizacji społeczeństwa. Mniemał w związku z tym, że skoro ludzie organizują

\footnotetext{
${ }^{23}$ Zainteresowanie polityczne Machiavellego odnośnie do społecznego i psychologicznego wymiaru relacji wewnątrz organizmu politycznego zostało szczególnie podkreślone przez N. Matteucci'ego, Machiavelli politologo w: M.P. Gilmore (Ed.), Studies on Machiavelli. Firenze 1972, 207-248 (np. 236, a zwł. 246-247).
} 
swe własne kolektywne życie, to mogliby również je zmienić tak, aby jeden z tych skutków uczynić niemożliwym. Machiavelli natomiast interpretował te siły $z$ innego, bardziej podstawowego punktu widzenia, mianowicie ze stanowiska podstawowej antropologii politycznej. Pewne potrzeby ciała politycznego są jednocześnie tendencjami natury ludzkiej: „lud” i „możni” są tylko historycznie uwarunkowanymi, politycznymi konfiguracjami dwóch temperamentów, woli podporządkowywania się i woli bycia niepodporządkowanym, pragnienia wyzyskiwania i pragnienia niebycia wyzyskiwanym. Oba usposobienia jako antropologiczne modi są konstytutywne dla wszystkich form politycznej organizacji, ponieważ żadna z nich nie może przetrwać bez siły chcącej władzy, bez sił, które przewodza, lub w sytuacji, gdy większość jej sił żywotnych jest tłamszona. Z tego powodu żadna $\mathrm{z}$ sił nie może zostać wyeliminowana, obie muszą znaleźć równowagę między sobą dla dobra całego organizmu: konflikt polityczny jest grą takiej regulacji, w której stawką jest wolność, godność, odpowiedzialność, dobrobyt i - co najważniejsze - samostanowienie ${ }^{24}$.

\section{0 antropologii i myśli politycznej}

To, co Machiavelli określa mianem „temperamentów” jest stałą parą przeciwieństw antropologii politycznej. Istnienie tych podstawowych, antropologicznych tendencji nie wynika z ich zróżnicowanych, historycznie określonych, społecznoekonomicznych wcieleń (przykładowo: klasy społeczne, partie polityczne, ruchy społeczne); żadna $\mathrm{z}$ tych konkretyzacji nie wyczerpuje odpowiadającej jej fundamentalnej, antropologicznej tendencji, bo obie tendencje są pierwotnie zakorzenione nie tyle $\mathrm{w}$ zmieniającej się historii, lecz $\mathrm{w}$ niezmiennej, zdaniem Machiavellego, naturze ludzkiej25. Ujmując rzecz inaczej, klasy społeczne i partie polityczne powstają i gina, ale usposobienia antropologiczne, których są przejawami, przechodzą jedynie proces transformacji, wynikiem którego są ich nowe społecznie, politycznie i kulturowo określone i przypadkowe postacie.

\footnotetext{
${ }^{24}$ W rzeczywistości Machiavelli mówi o podmiotach politycznych jako „ciałach” politycznych, ale ponieważ cała jego teoria oparta jest na żywotnej konieczności nieskrępowanej, wewnętrznej walki politycznej, nie jest to zatem ciało organiczne i nie wspiera ono idei państwa korporacyjnego ani też paternalistycznego.

${ }^{25}$ Idea niezmienności natury ludzkiej jest niewątpliwie jednym z ograniczeń myśli Machiavellego: ze współczesnego ewolucyjnego punktu widzenia sprawia wrażenie zupełnie metafizycznej. Jednakże naturalne zmiany ewolucyjne zachodzą zwykle w czasie nieskończenie dłuższym niż okres czasu, który ma znaczenie w bieżącym (tj. przewidywalnym) działaniu politycznym. Jednakże, Machiavelli posługuje się tą ideą $\mathrm{w}$ celach heurystycznych raczej niż w sensie metafizycznym: nie dedukuje $\mathrm{z}$ niej porządku politycznego.
} 
Słusznym będzie oczekiwać istnienia względem omawianych tu "temperamentów" głębszej, antropologiczno-politycznej stałej, której znaczenie Machiavelli sam podkreślał jako konieczny warunek polityki: ambicji. Byłoby jednak błędem utożsamiać ambicję z najbardziej podstawowym elementem teorii Machiavellego, ponieważ według niego sama ambicja jest z kolei niczym innym jak wyrazem strukturalnej - i dlatego - bardziej fundamentalnej cechy natury ludzkiej, mianowicie różnicy czy też dysproporcji pomiędzy pragnieniem a możliwością jego zaspokojenia ${ }^{26}$. Współczesna antropologia filozoficzna również zakłada taką różnicę jako fundamentalne prawo antropologiczne, ale idzie dalej i głębiej w swoim przedpolitycznym opisie i wyjaśnieniu tej oraz innych podstawowych kategorii i cech natury ludzkiej, związanych z definicją szczególnego stanowiska, jakie gatunek ludzki zajmuje w kosmosie (Scheler), w przyrodzie ożywionej (Plessner) oraz w świecie (Gehlen) ${ }^{27}$. W takiej perspektywie dysproporcja pomiędzy pragnieniem a rzeczywistością odnosi się do pulsacyjnej natury ludzkiego życia, której istotę wyznacza "szczególne stanowisko" (określane przez Plessnera mianem "umiejscowienia ekscentryczneego", ekzentrische Positionalität, a przez Gehlena mianem "istoty wybrakowanej", Mängelwesen ${ }^{28}$ ).

\section{0 pewnym otwartym problemie ery postkomunistycznej}

Jedną z politycznych konsekwencji końca zimnej wojny jest ta, która stanowi zagrożenie zdrowego funkcjonowania współczesnych systemów politycznych: odnoszę się tu do "globalizacji” i pełnej przemocy walki, która ją otacza. W istocie rzeczy wciąż brakuje demokratycznej rekonstrukcji porządku światowego w czasach po zimnej wojnie. Obserwujemy, z jednej strony, tendencję do narzucania nowych porządków, tak jakby ludzkie dążenie do większej równości i możliwości samostanowienia zniknęło wraz z systemami totalitarnymi, które dążenia te

\footnotetext{
${ }^{26}$ Zob. przykładowo Discorsi, I, 37, 2.: qualanque volta è tolto agli uomini il combattere per necessità, combattono per ambizione; la quale è tanto potente ne petti umani, che mai, a qualanque grado si salgano, gli abbandona. La cagione è, perché la natura ha creati gli uomini in modo, che possono desiderare ogni cosa, e non possono conseguire ogni cosa: talché, essendo sempre maggiore il desiderio che la potenza dell'acquistare, ne risulta la mala contentezza di quello che si possiede, e la poca sodisfazione d'esso (Machiavelli, Rozważania..., 216: „jeśli konieczność nie zmusza ich do prowadzenia wojen, prowadzą je z ambicji. Ta ostatnia jest namiętnością tak potężną że nie opuszcza ludzi nigdy, niezależnie od wszelkich godności, jakie piastują. Przyczyna tego jest następująca: natura stworzyła człowieka takim, że wszystkiego może pragnąć, ale nie wszystko osiągnąć; pragnienie jest zatem zawsze większe od zdolności nabycia - stąd niezadowolenie $\mathrm{z}$ tego, co się posiada.")

${ }^{27}$ Zob. np. Gehlena ujęcie tego wątku w: A. Gehlen, Gesamtausgabe, t. 4, Philosophische Anthropologie und Handlungslehre, Frankfurt/M. 1983, rozdz. pt. Ein anthropologisches Modell, 203-216, tu 211-213.

${ }^{28}$ Doskonałym wprowadzeniem do niemieckiej antropologii filozoficznej jest J. Fischera Philosophische Anthropologie. Eine Denkrichtung des 20. Jahrhunderts. Freiburg/Br. 2008 (Studienausgabe 2009).
} 
zinstrumentalizowały; z drugiej strony, obserwujemy nieudolne reakcje na taką polityczną ofensywę. Z perspektywy teorii konfliktu politycznego, której autorem jest Machiavelli, takie tendencje stanowią destrukcyjne przeciwieństwo.

Machiavelli doskonale zdawał sobie sprawę z naturalnej równości pomiędzy ludźmi i z ich nierównej pozycji społecznej29. Nie zgadzał się ani z próbami zastąpienia porządku społecznego przez stan natury, ani też nie popierał ustanowienia porządku społecznego w pełni oderwanego od stanu natury. W obu przypadkach był przeciwko jednostronnej konfiguracji systemów politycznych. Jego celem było znalezienie kompromisu pomiędzy oczywistymi egoistycznymi pobudkami jednostki a społeczną regulacją tych egoistycznie motywowanych działań. Społeczeństwa europejskie ery postkomunizmu zdają się być wciąż na drodze do odnalezienia takiej równowagi. Powinny wypracować taką kulturę konfliktu politycznego, jakiej stylizatorem w odniesieniu do starożytnej Republiki Rzymskiej był Machiavelli, ale powinny unikać łączenia dynamiki ich wewnętrznego konfliktu politycznego z zagranicznym ekspansjonizmem militarnym jako pozytywnym modelem Republiki starożytnego Rzymu przedstawionym przez Machiavellego. Spełnienie pierwszego postulatu jest powiązane m.in. z ideą mówiąca, że bycie częścią organizmu politycznego oznacza jego polepszenie przez uczynienie samostanowienia (społecznego, kulturowego, obywatelskiego) modelem ludzkiego działania. Drugi postulat jest być może nowym i trudnym, ale koniecznym wyzwaniem dla ciał politycznych, którego Machiavelli nie mógł sobie wyobrazić i do którego spełnienia powinniśmy nieustannie dążyć: silna, pokojowa i autonomiczna Zjednoczona Europa.

Z języka angielskiego przełożył Marek Fabianowski

\section{Literatura}

Badaloni, N. 2005. Inquietudini e fermenti di libertà. ETS, Pisa.

Fischer, J. 2008, 2009. Philosophische Anthropologie. Eine Denkrichtung des 20. Jahrhunderts. Alber: Freiburg.

Gehlen, A. 1983. Gesamtausgabe, Bd. 4, Philosophische Anthropologie und Handlungslehre. Vittorio Klostermann: Frankfurt/M.

Gilmore, M.P. (Ed.) 1972. Studies on Machiavelli. Sansoni: Firenze.

\footnotetext{
${ }^{29}$ Por. Historie florenckie, III, 13. Bardzo dobra, wszechstronną i wciąż aktualną interpretacją pozostaje N. Badaloni'ego Natura e società in Machiavelli, op. cit.
} 
Machiavelli, N. 1989. The Chief Works and Others, tłum. A. Gilbert, Durham - London.

Machiavelli, N. 1990. Historie florenckie. PWN: Warszawa - Kraków.

Machiavelli, N. Ksiaże, tłum. W. Rzymanowski. Unia Wydawnicza Verum, Warszawa 2005.

Machiavelli, N. 1986. Mandragola, tłum. E. Boyè. Wydawnictwa Artystyczne i Filmowe: Warszawa.

Machiavelli, N. 2005. Rozważania nad pierwszym dziesięcioksięgiem historii Rzymu Liwiusza, tłum. Unia Wydawnicza Verum: Warszawa.

Machiavelli, N. 1989. The Chief Works and Others, tłum. A. Gilbert, Vol. 2. Duke University Press: Durham - London.

Procacci, G. 1995. Machiavelli nella cultura europea dell'età moderna. Laterza: Roma.

Ridolfi, R. 1954. Vita di Niccolò Machiavelli. Belardetti: Roma.

Tommasini, O. 1883-1911. La vita e gli scritti di Niccolò Machiavelli. Loescher: Torino Roma.

Villari, P. 1912-1914. Niccolò Machiavelli e i suoi tempi. Hoepli: Milano.

Viroli, M. 1998. Il sorriso di Niccolò. Storia di Machiavelli. Laterza: Roma. 
Mario Marino (Nietzsche-Kolleg, Weimar)

\title{
Political Conflict and Human nature: Machiavelli's Reflection upon Ancient Rome and Modern Florence and its Potentials for Developing Democratic Consciousness in Contemporary World
}

\begin{abstract}
The present paper stresses from a philological and anthropological point of view Machiavelli's potential for thinking and practicing democracy in modern times. The first part disputes some Machiavellian myths, philologically demonstrating for example that Machiavelli never thought that 'end justifies the means'. The second part brings to light the anthropological fundamentals of Machiavelli's theory of political conflicts: special attention is paid to the doctrine of the opposite tendencies within the political bodies (the wish to command and the wish not to obey, the desire of oppressing and that of not to be oppressed) as well as to the theory of anthropological roots of ambition. The third and final part compares Machiavelli's anthropological theory of political conflicts with both Marx's economic interpretation of political conflicts and German philosophical anthropological explanation of human nature (Gehlen, Scheler, Plessner).
\end{abstract}

Keywords. Anthropological foundation of political philosophy autonomy, authority, citizens' condition, democracy, freedom, Machiavelli, origins of modern political thought, political and social conflict.

Citations. Marino, M. (2012). Konflikt polityczny i natura ludzka: Machiavellego rozważania nad starożytną Republiką Rzymską i nowożytną Florencją oraz ich wpływ na współczesną świadomość demokratyczną. Ethics in Progress Quarterly, Volume 3, Issue 1, pp. 111-127, available online at ethicsinprogress.org. 